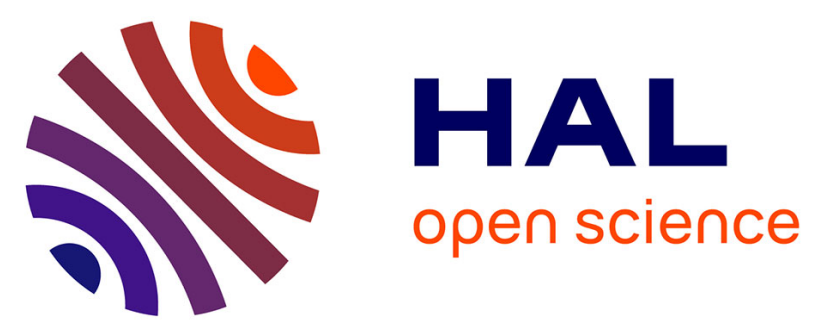

\title{
Impact of Perceived Connectivity on Intention to Use Social Media: Modelling the Moderation Effects of Perceived Risk and Security
}

\author{
Samuel Fosso Wamba, Shahriar Akter
}

\section{- To cite this version:}

Samuel Fosso Wamba, Shahriar Akter. Impact of Perceived Connectivity on Intention to Use Social Media: Modelling the Moderation Effects of Perceived Risk and Security. 15th Conference on e-Business, e-Services and e-Society (I3E), Sep 2016, Swansea, United Kingdom. pp.219-227, 10.1007/978-3-319-45234-0_20 . hal-01702181

\section{HAL Id: hal-01702181 \\ https://hal.inria.fr/hal-01702181}

Submitted on 6 Feb 2018

HAL is a multi-disciplinary open access archive for the deposit and dissemination of scientific research documents, whether they are published or not. The documents may come from teaching and research institutions in France or abroad, or from public or private research centers.
L'archive ouverte pluridisciplinaire HAL, est destinée au dépôt et à la diffusion de documents scientifiques de niveau recherche, publiés ou non, émanant des établissements d'enseignement et de recherche français ou étrangers, des laboratoires publics ou privés. 


\title{
Impact of Perceived Connectivity on Intention to Use Social Media: Modelling the Moderation Effects of Perceived Risk and Security
}

\author{
Samuel Fosso Wamba ${ }^{1}$ and Shahriar Akter ${ }^{2}$ \\ ${ }^{1}$ Toulouse Business School, 20 Boulevard Lascrosses, 31068 Toulouse, France \\ ${ }^{2}$ Faculty of Business, University of Wollongong, Northfields Ave, Wollongong NSW 2522, \\ Australia \\ \{fossowam@gmail.com, sakter@uow.edu.au\}
}

\begin{abstract}
The main objective of this study is to assess the impact of perceived connectivity (PC) on the intention to use (IU) social media in organizations, as well as the moderating effects of perceived risk (PR) and perceived security (PS) on this relationship. Data were collected from 2,556 social media users across Australia, Canada, India, the UK, and the US to test our proposed research model. Our results found that PC has a significant positive effect on the IU social media in organizations, and non-significant moderating effects of PR and PS. The study concludes with the implications for practice and research.
\end{abstract}

Keywords: social media, adoption and use, intention, perceived connectivity, perceived risk, perceived security, moderation.

\section{Introduction}

Social media tools are currently emerging as the new means for value creation and realization for many organizations across all industries. Indeed, social media tools (e.g., Facebook, Twitter) have the capability of transforming the way firms conduct their businesses, by allowing for example, an improved way of identifying products with high market potential [1], a superior mechanism for engaging (e.g., attract and retain) with online consumers [2], a robust platform for marketing communication [3], and a better collaboration channel with all firm stakeholders [4, 5]. It is probably for these reasons that some scholars argue that social media are at the core of the "social commerce", which is considered as the new wave of electronic commerce, and defined as "a form of Internet-based social media that allows people to participate in the marketing, selling, comparing, and buying of products and services in online marketplaces and communities" (p. 215) [6].

The high operational and strategic potential of social media as enabler of organizational change for competitive advantage has been acknowledged by the professional literature as well as the emerging research on the topic. However, technological innovation history tells us that the path toward the wide acceptance of any given innovation by businesses can be quite long. Therefore, it is critical to look at the key determinants that may drive the adoption and use of social media by 
organizations. More specifically, this study examines the following research questions:

1. What is the impact of perceived connectivity on the intention to use social media in organizations?

2. What is the moderating effect of perceived risk and security on this relationship?

To address these research questions, the study explores the embryonic literature on social media, the diffusion of innovation theory, risk and security issues to develop a conceptual research model. More precisely, we argue that social media's perceived connectivity will have a positive impact on the intention to use social media. Then, perceived risk and perceived security will have moderating effects on the said relationship. The proposed model was tested using data from 2,556 social media users for their daily activities across various industries in Australia, Canada, India, the UK, and the US. The rest of the paper is structured as follows: first, we present the conceptual model and hypotheses; next, we discuss the research methodology; the following section presents the results; then we present the discussion, implications, limitations and future research perspectives; finally, we present the conclusion of the study.

\section{THEORETICAL DEVELOPMENT}

From the emerging literature on social media, the diffusion of innovation theory, risk and security issues, a conceptual model based is presented in Figure 1. In the model, we argue that Perceived connectivity (PC) of social media in organizations will have a positive impact on the intention to use (IU) social media. However, this relationship will be moderated by both perceived risk (PR) and perceived security (PS).

Perceived connectivity which is defined as the ability of a social media platform to bring together people who share common interests or goals [7] is considered as an important determinant of IT adoption and use [8,9]. The importance of this construct is even greater for interactive innovations since their adoption and effective use by a critical mass of users will impact positive network externalities on all users [10]. Evidence supporting this postulate exists in prior studies on the user acceptance of enterprise instant messaging [8], and the acceptance of electronic mail (e-mail) and instant messaging (IM) [9].

Perceived risk and perceived security play an important role in IT adoption and use. Perceived risk is defined as "the extent to which a functional or psychosocial risk a user feels he/she is taking when using a product", whereas perceived security is defined as "the subjective probability with which users believe their sensitive information (business or private) will not be viewed, stored, and manipulated during work sessions by unauthorized parties in a manner consistent with their confident expectations" (p. 165) [8].

Due to the emergence of Web 2.0 and social media in the last decade, there is an increasing trend in the creation and exchange of user generated contents. People express themselves in virtual communities for communication, networking or amusement through constant interaction in the form of information creation, redistribution and exchange[11]. Indeed, social network sites and many online platforms are used by individuals to share private information effortlessly and seamlessly in great detail and volume[11]. These massive amounts of data, referred 
to as big data, often used for personalized offers or targeting potential customers. However, Akter \& Wamba [12] report that unexpected consequences can have on perceived risk and security when marketers target consumers in the big data environment. Because, it raises the question of safe handling of individual and organizational privacy and data security (e.g., names and addresses, social security numbers, credit card numbers, and financial information). Although consumers increasingly share personal information in e-commerce sites or in social networks, it is expected for firms not to breach consumers' privacy because consumers disclose information expecting it to be confidential under 'terms of use'[13]. Despite consumers' expectations for anonymous data to protect their security and risk, the ever growing big data environment and social commerce raise the question of perceived risk and security. Scholars have identified the current environment as informal and poorly structured [14, 15]. Moreover, prior studies on social media adoption and use by organizations have identified perceived risk [3] and perceived security as s factors that can slow down their adoption.

Thus, we propose the following hypotheses:

H1: PC has a significant positive effect on the IU social media in organizations.

H2: PR negatively moderates the relationship between PC and IU social media in organizations.

H3: PS positively moderates the relationship between PC and IU social media in organizations

Figure 1. Research Model

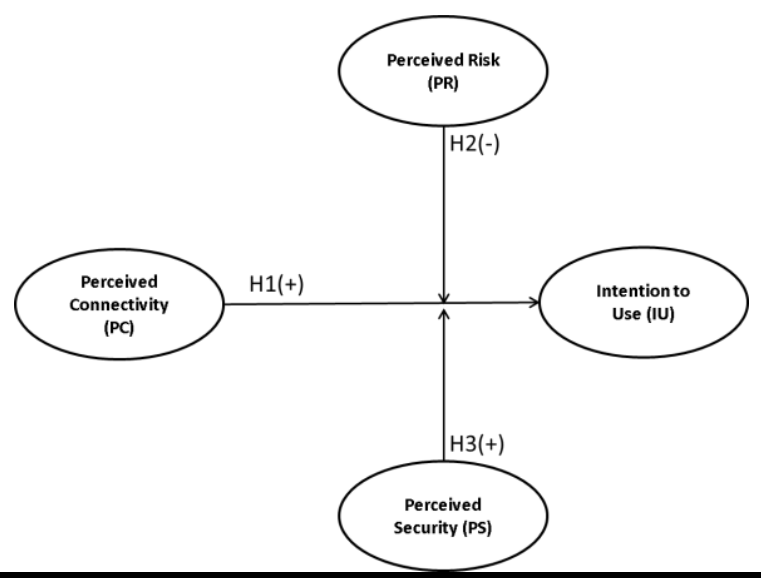

\section{Methodology}

This study is part of a larger study conducted by the Institute for Innovation in Business and Social Research (IIBSoR) of the University of Wollongong in Australia.. 
In this study, a web based-survey employed to collect data from 2,556 social media users within their workplaces in Australia, Canada, India, the UK, and the US in January 2013. The data collection process was handled by a leading international market research provider called Survey Sampling International (SSI). All items used in the study were taken from prior studies and adapted to the context of social media adoption and use in organizations [8, 16]. They were measured using 7-point Likert scale with anchors ranging from Strongly Disagree (1) to Strongly Agree (7) (Appendix).

For the data analysis, a statistical Excel add-in tool called XLSTAT-PLS (version of 2013.6.04) was used using Partial Least Squares (PLS) based Path Modeling . In this study, the reliability and validity of the items were evaluated. For model assessment, all item loadings values that are higher than 0.70 are considered to be adequate. A composite reliability value that is higher than 0.70 is considered to be acceptable [17]. For average variance extracted (AVE), a value that is higher than 0.50 is considered as acceptable measure justifying the use of a construct [17].

For the moderating effects testing, we use the two stage approach proposed by [3] using XLSTAT as following [18]: (1) we ran the main effect model, (2) extract the latent variable scores, (3) use the extracted latent variable scores as indicators of the exogenous and endogenous variables, and (4) use the element wise product of the latent variable scores of the exogenous variable and the moderator variable as the indicator of the interaction term.

\section{ReSUltS AND DISCUSSION}

Table 1 presents the descriptive statistics of our manifest variables. PC is the latent variable with the items with the highest means. Indeed, all PC items have a mean greater than five (5) with items measure using a Likert scale ranging from 1 to 7 . On the other hands, PS is the latent variable with the lowest items values (3.68 and 3.706).

Table 2 displays all factor loadings, Cronbach's alpha values, composite reliability and average variance extracted (AVE) of the latent variables. From Table 2, we can see that all values meet the recommended acceptable threshold values - respectively, $0.6,0.7,0.7$ and 0.5 [19] - and consequently justify the use of all our constructs in the model.

Table 3 represents the correlation matrix with the square root of the AVEs in the diagonals. From the table, we can see that all values exceed the inter-correlations of the construct with the other constructs in the model, and therefore confirming the discriminant validity [20-22]. In fact, the discriminant validity is confirmed when all the bold values on the diagonal representing the square root of the AVE are higher than the inter-correlations of all constructs in the model. 
Table 1. Descriptive Statistics of Measured Manifest Variables

\begin{tabular}{llllll}
\hline Latent variable & Items & Minimum & Maximum & Mean & Std. deviation \\
\hline \multirow{3}{*}{ PC } & PC1 & 1 & 7 & 5.154 & 1.685 \\
& PC2 & 1 & 7 & 5.047 & 1.755 \\
& PC3 & 1 & 7 & 5.162 & 1.693 \\
& PC4 & 1 & 7 & 5.565 & 1.557 \\
\hline \multirow{3}{*}{ IU } & IU1 & 1 & 7 & 3.748 & 2.076 \\
& IU2 & 1 & 7 & 4.597 & 2.011 \\
& IU3 & 1 & 7 & 3.752 & 2.099 \\
PS & IU4 & 1 & 7 & 4.598 & 1.989 \\
\hline \multirow{2}{*}{ PR } & PS1 & 1 & 7 & 3.680 & 1.841 \\
& PS2 & 1 & 7 & 3.706 & 1.790 \\
\hline
\end{tabular}

Table 2. Factor Loadings, Cronbach's Alpha, Composite Reliability and AVE

\begin{tabular}{|c|c|c|c|c|c|}
\hline $\begin{array}{l}\text { Latent } \\
\text { variable }\end{array}$ & Items & $\begin{array}{l}\text { Standardized } \\
\text { loadings }\end{array}$ & $\begin{array}{l}\text { Cronbach's } \\
\text { alpha }\end{array}$ & D.G. rho (PCA) & $\overline{A V E}$ \\
\hline \multirow[t]{4}{*}{$\mathrm{PC}$} & $\mathrm{PC1}$ & 0.948 & 0.890 & 0.929 & 0.749 \\
\hline & $\mathrm{PC} 2$ & 0.919 & & & \\
\hline & PC3 & 0.942 & & & \\
\hline & $\mathrm{PC} 4$ & 0.606 & & & \\
\hline \multirow[t]{4}{*}{ IU } & IU1 & 0.842 & 0.902 & 0.932 & 0.776 \\
\hline & IU2 & 0.920 & & & \\
\hline & IU3 & 0.844 & & & \\
\hline & IU4 & 0.914 & & & \\
\hline \multirow[t]{2}{*}{ PS } & PS1 & 0.973 & 0.942 & 0.972 & 0.945 \\
\hline & PS2 & 0.971 & & & \\
\hline \multirow[t]{2}{*}{ PR } & PR1 & 0.994 & 0.809 & 0.913 & 0.780 \\
\hline & PR2 & 0.756 & & & \\
\hline
\end{tabular}

Table 4 presents a value of 0.644 for the absolute goodness of fit (GoF) and a value of 0.980 for the relative GoF, which are all above the threshold values. Indeed, an absolute GoF greater than 0.5 is considered satisfactory, and a relative GoF that is 
close to 0.90 is considered as a great fit of a model [23], and accordingly, we can conclude that the research model has an excellent fit.

Figure 2 presents the research results. From the figure, we see that the standardized path coefficient of the relationship between PC and IU social media in organizations is significant at a level of 0.001 , and thus supporting our hypothesis (H1). However, all the standardized path coefficients related to the moderating effects of PR and PS are not significant, and therefore, we have to reject $\mathrm{H} 2$ and $\mathrm{H} 3$. In addition, the coefficient of determination, $\mathrm{R}^{2}$ is 0.521 for the IU social media in organizations, thus suggesting a good fit of the data with our proposed model.

Consistent with prior studies $[9,18]$, this study found that PC of social media is a significant predictor of IU. This result confirms that users perceived positive network externalities of social media have a positive impact on their use of social media [9]. However, the study found no moderating effects of PR and PS on the relationship between PC and IU. A possible explanation of this result may be the fact that within organizations, several protection mechanisms related to the use of media have been implemented to create a safe usage environment.

Table 3. Correlations matrix (The bold values on the diagonal are the square root of the AVE)

\begin{tabular}{lllll}
\hline & PC & PS & PR & IU \\
\hline PC & $\mathbf{0 . 8 6 5}$ & & & \\
PS & 0.271 & $\mathbf{0 . 9 7 2}$ & & \\
PR & -0.050 & -0.189 & $\mathbf{0 . 8 8 3}$ & \\
IU & 0.506 & 0.626 & -0.198 & $\mathbf{0 . 8 8 1}$ \\
\hline
\end{tabular}

Table 4. Goodness of fit index

\begin{tabular}{ll}
\hline & Goodness of fit index \\
\hline Absolute & 0.644 \\
Relative & 0.980 \\
\hline
\end{tabular}




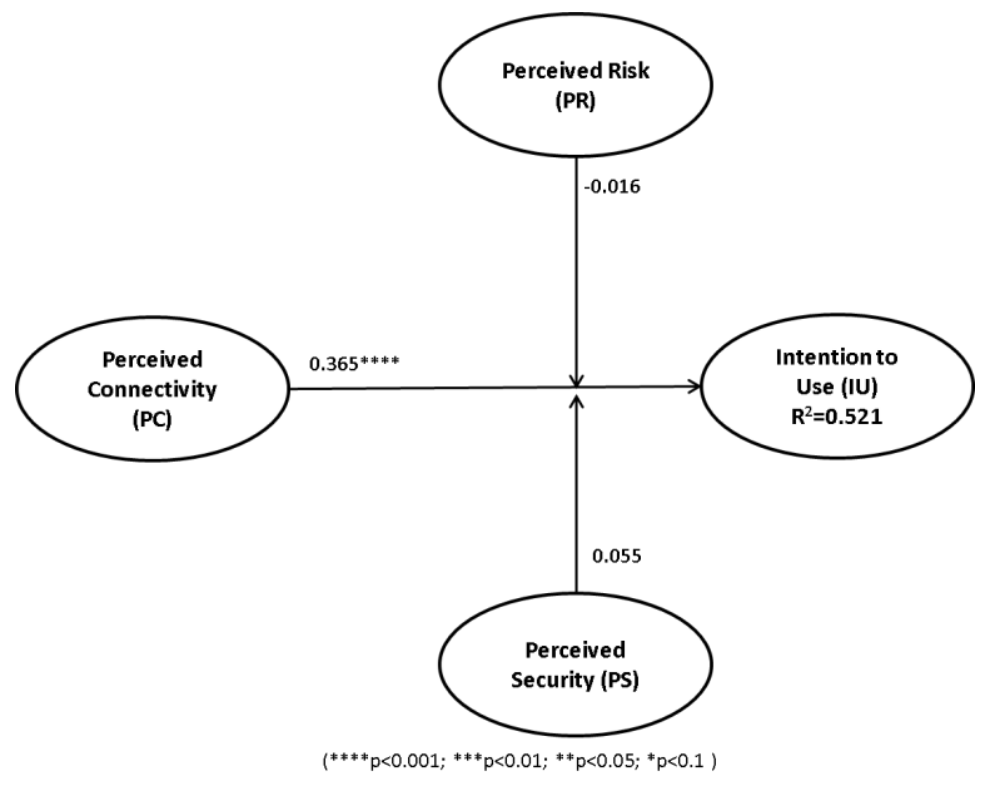

\section{CONCLUSION AND FUTURE RESEARCH DIRECTIONS}

The main objective of this paper was to assess the impact of perceived connectivity (PC) on the intention to use (IU) social media in organizations, as well as the moderating effects of perceived risk (PR) and security (PS) on this relationship. Our proposed model provides strong empirical evidence that perceived connectivity positively impact users' intention to use social media in organizations. However, the study found no moderating effects of both perceived risk and security.

Still, the big data driven social media environment raises enormous questions on risk and security as a result of mass scale surveillance, manipulation, and profiling. Undoubtedly, the current environment has challenged the autonomy of individuals by neglecting their consent and acknowledgment. Since social connectivity are increasingly used for security, marketing, health, business, and many other social aspects, the predictions and decisions that are made using social data should be scientific, error- free and objective.

The study presents some limitations: First, the data were collected using a crosssectional design. Future studies should consider using a longitudinal study or case study to gain a deeper understanding related to social media adoption and use within organizations. Second, the study doesn't assess cultural differences within the sample. Future research could focus on analysing the impact of cultural factors on the adoption and use of social media within organizations. Third, this study doesn't 
consider a specific type of social media platform. In fact, prior studies suggest that adoption factors vary depending on the type of social media platform under study [24]. Therefore, future studies could focus on one specific type of social media platform.

\section{References}

1. Liang, T.-P. and E. Turban, Special Issue on Social Commerce. International Journal of Electronic Commerce, 2011.

2. IBM, Social Commerce Defined, IBM, Editor. 2009, IBM.

3. Munnukka, J. and P. Järvi, Perceived risks and risk management of social media in an organizational context. Electronic Markets, 2014. 24(3): p. 219229.

4. Culnan, M.J., P.J. McHugh, and J.I. Zubillaga, How large U.S. companies can use twitter and other social media to gain business value. MIS Quarterly Executive, 2010. 9(4): p. 243-259.

5. Burke, W.Q., D.A. Fields, and Y.B. Kafai, Entering the clubhouse: case studies of young programmers joining the online scratch communities, in Journal of Organizational and End User Computing. 2010. p. 21+.

6. Stephen, A.T. and O. Toubia, Deriving Value from Social Commerce Networks. Journal of Marketing Research, 2010. 47(2): p. 215-22.

7. Benbasat, I., A program of studies to improve the communication between customers and online stores, in Human-computer Interaction and Management Information Systems: Applications, D.F. Galletta and P. Zhang, Editors. 2006, Advances in Management Information Systems.

8. Trinchera, L., Unobserved Heterogeneity in Structural Equation Models: a new approach to latent class detection in PLS Path Modeling. 2007, Universit a degli Studi di Napoli Federico II: Napoli. p. 338.

9. Strader, T.J., S.N. Ramaswami, and P.A. Houle, Perceived network externalities and communication technology acceptance. European Journal of Information Systems, 2007. 16(1): p. 54-65.

10. Fosso Wamba, S. and A.T. Chatfield, A contingency model for creating value from RFID supply chain network projects in logistics and manufacturing environments. European Journal of Information Systems, 2009. 18(6): p. 615-636.

11. Gritzalis, D., et al. History of Information: The case of Privacy and Security in Social Media. in Proc. of the History of Information Conference. 2014.

12. Akter, S. and S.F. Wamba, Big data analytics in E-commerce: a systematic review and agenda for future research. Electronic Markets, 2016: p. 1-22.

13. Martin, K.E., Ethical Issues in the Big Data Industry. MIS Quarterly Executive, Forthcoming, 2015.

14. Pantelis, K. and L. Aija. Understanding the value of (big) data. in 2013 IEEE International Conference on Big Data. 2013.

15. George, G., M.R. Haas, and A. Pentland, Big data and management. Academy of Management Journal, 2014. 57(2): p. 321-326. 
16. Davis, F.D., Perceived usefulness, perceived ease of use, and user acceptance of information technology. MIS Quarterly, 1989. 13(3): p. 319340.

17. Leung, J., W. Cheung, and S.-C. Chu, Aligning RFID Applications with Supply Chain Strategies. Information \& Management, (0).

18. Luo, X., A. Gurung, and J.P. Shim, Understanding the Determinants of User Acceptance of Enterprise Instant Messaging: An Empirical Study. Journal of Organizational Computing and Electronic Commerce, 2010. 20(2): p. 155181.

19. Guadagnoli, E. and W. Velicer, Relation of sample size to the stability of component patterns Psychological Bulletin, 1988. 103: p. 265-275.

20. Chin, W.W., The partial least squares approach for structural equation modeling. 1998.

21. Chin, W.W., How to write up and report PLS analyses. Handbook of partial least squares, 2010: p. 655-690.

22. Fornell, C. and D.F. Larcker, Evaluating structural equation models with unobservable variables and measurement error. Journal of Marketing Research, 1981: p. 39-50.

23. Rahimnia, F. and J.F. Hassanzadeh, The impact of website content dimension and e-trust on e-marketing effectiveness: The case of Iranian commercial saffron corporations. Information \& Management, 2013. 50(5): p. 240-247.

24. Fosso Wamba, S. and L. Carter, Twitter Adoption and Use by Smes: An Empirical Study, in The 46 Hawaii International Conferences on System Sciences (HICSS). 2013: Maui, Hawaii, US. 
Appendix: Adapted from [18]

\begin{tabular}{|c|c|c|c|c|c|c|c|}
\hline & $\begin{array}{l}\text { Strongly } \\
\text { Disagree }\end{array}$ & $\begin{array}{l}\text { Moderately } \\
\text { Disagree }\end{array}$ & $\begin{array}{c}\text { Slightly } \\
\text { Disagree }\end{array}$ & Undecided & Slightly Agree & $\begin{array}{l}\text { Moder } \\
\text { ately } \\
\text { Agree }\end{array}$ & $\begin{array}{c}\text { Strongly } \\
\text { Agree }\end{array}$ \\
\hline \multicolumn{8}{|c|}{ Perceived Connectivity } \\
\hline $\begin{array}{l}\text { Most of my colleagues use } \\
\text { social media tools }\end{array}$ & 1 & 2 & 3 & 4 & 5 & 6 & 7 \\
\hline $\begin{array}{l}\text { Among the colleagues I } \\
\text { communicate with regularly, } \\
\text { many use social media tools }\end{array}$ & 1 & 2 & 3 & 4 & 5 & 6 & 7 \\
\hline $\begin{array}{l}\text { A large percentage of my } \\
\text { colleagues use social media } \\
\text { tools }\end{array}$ & 1 & 2 & 3 & 4 & 5 & 6 & 7 \\
\hline $\begin{array}{l}\text { From my observation, the } \\
\text { number of social media tools } \\
\text { users is large }\end{array}$ & 1 & 2 & 3 & 4 & 5 & 6 & 7 \\
\hline \multicolumn{8}{|c|}{ Intention to Use } \\
\hline $\begin{array}{l}\text { If I have to temporarily use a } \\
\text { computer without social media } \\
\text { tool(s), I intend to install it } \\
\text { (them). }\end{array}$ & 1 & 2 & 3 & 4 & 5 & 6 & 7 \\
\hline $\begin{array}{l}\text { If I own a computer with social } \\
\text { media tool(s), I intend to use it } \\
\text { (them). }\end{array}$ & 1 & 2 & 3 & 4 & 5 & 6 & 7 \\
\hline $\begin{array}{l}\text { Given that I have a computer } \\
\text { with social media tool(s), I } \\
\text { predict that I will use it (them) } \\
\text { at work. }\end{array}$ & 1 & 2 & 3 & 4 & 5 & 6 & 7 \\
\hline $\begin{array}{l}\text { I plan to use social media tools } \\
\text { in the near future. }\end{array}$ & 1 & 2 & 3 & 4 & 5 & 6 & 7 \\
\hline
\end{tabular}

\begin{tabular}{|c|c|c|c|c|c|c|c|}
\hline \multicolumn{8}{|c|}{ Perceived Risk } \\
\hline $\begin{array}{l}\text { I think using social media tools } \\
\text { is risky. }\end{array}$ & 1 & 2 & 3 & 4 & 5 & 6 & 7 \\
\hline $\begin{array}{l}\text { Using social media tools will } \\
\text { bring risk to my work }\end{array}$ & 1 & 2 & 3 & 4 & 5 & 6 & 7 \\
\hline \multicolumn{8}{|c|}{ Perceived Security } \\
\hline $\begin{array}{l}\text { I think my information on } \\
\text { social media tools is secure. }\end{array}$ & 1 & 2 & 3 & 4 & 5 & 6 & 7 \\
\hline $\begin{array}{l}\text { Using social media tools is } \\
\text { secure }\end{array}$ & 1 & 2 & 3 & 4 & 5 & 6 & 7 \\
\hline
\end{tabular}

